\title{
KEBUTUHAN HAK PENDIDIKAN MINORITAS
}

\author{
Linda Herlina \\ Institut Ilmu Sosial Dan Ilmu Politik Yapis Biak
}

Email: linda01@gmail.com

\begin{abstract}
Abstrak
India, negara demokrasi terbesar di dunia adalah negeri dengan keragaman agama, budaya, dan bahasa. Sejalan dengan itu, kami memiliki pembagian populasi menjadi mayoritas dan beberapa minoritas berdasarkan komunitas agama, budaya, serta bahasa. Tujuan dasar dari perlindungan minoritas adalah untuk menanamkan kepercayaan kepada mereka, menciptakan perasaan bahwa mereka tidak akan pernah dikuasai oleh mayoritas dan untuk menyeragamkan kemajemukan dalam masyarakat sipil dan untuk mengintegrasikan minoritas secara penuh dan setara ke dalam kehidupan nasional negara yang bercirikan etos dan kepentingan mayoritas. Istilah minoritas hanya muncul dalam Pasal 29 dan 30 Konstitusi India. Pasal 30 mengakui hak minoritas baik berdasarkan agama atau bahasa untuk mendirikan dan menyelenggarakan lembaga pendidikan pilihan mereka dan melarang negara untuk mendiskriminasi lembaga pendidikan atas dasar bahwa ia di bawah pengelolaan minoritas. Pasal 30 (1) mendapat tempat yang sangat khusus karena melalui pendidikan saja minoritas dapat melestarikan bahasa, aksara dan warisan budaya mereka. Itu adalah faktor terpenting bagi perkembangan manusia serta masyarakat. Bahkan hukum internasional mengakui bahwa pendidikan adalah hak asasi manusia secara umum dan juga bagian penting dari hak minoritas. Konsep minoritas meskipun tidak ditentukan oleh Konstitusi muncul lagi dalam Pasal 29 konstitusi, di mana hak setiap bagian dari warga negara yang tinggal di wilayah India, 'untuk' melestarikan 'bahasa, aksara atau Budaya yang berbeda dilindungi. Apalagi Pasal 25 hingga Pasal 28 UUD melindungi hak-hak agama dan budaya kaum minoritas. Selain hak-hak ini, pasal-pasal dalam Bagian III Konstitusi yang menjamin hak-hak fundamental tertentu baik untuk warga negara perorangan atau semua orang, baik warga negara atau bukan, sangat memperkuat perlindungan ini. Ini mencari perlindungan aktivitas individu anggota kelompok atau bagian dari populasi baik yang beroperasi secara terpisah atau bersama-sama. Mereka sering diarahkan untuk mempromosikan kelompok-kelompok ini atau aktivitas mereka. Pasal 29 dan 30 konstitusi menjamin beberapa hak yang ditentukan dan beberapa hak yang tidak ditentukan untuk kelompok minoritas ini. Hak untuk mendirikan dan mengelola lembaga pendidikan pilihannya, misalnya, merupakan hak khusus yang dijamin oleh minoritas bahasa dan agama. Lembaga semacam itu dapat didirikan dan dikelola oleh setiap bagian warga negara yang memiliki bahasa, aksara atau budaya yang berbeda untuk melestarikannya. Yang terakhir juga dapat mengambil langkah yang wajar untuk melestarikan bahasa, naskah, atau budaya. Namun yang terpenting alasan pemberian
\end{abstract}

JURNAL PAPATUNG: Vol. 2 No. 1 Tahun 2019

ISSN: 2715-0186 
hak tersebut adalah kenyataan bahwa kelompok minoritas menyadari bahwa mereka membutuhkan pendidikan untuk kelangsungan hidup dan perkembangan. Jika ingin melestarikan identitas budayanya maka akan cenderung mendirikan lembaga pendidikan di mana anggotanya dapat memiliki suasana yang menyenangkan yang kondusif bagi tumbuhnya identitasnya. Filosofi yang mendasari konstitusi adalah bahwa tidak ada minoritas baik berdasarkan agama, masyarakat atau bahasa yang dirampas haknya atau didiskriminasi dalam hal masuk ke lembaga pendidikan negara.

Kata kunci: Minoritas, Hak Pendidikan, Pasal 29, Pasal 30, Konstitusi

\begin{abstract}
India, the largest democracy in the world, is a country of diversity of religions, cultures and languages. Correspondingly, we have divided the population into majority and minority groups based on religious, cultural and linguistic communities. The basic aim of protecting minorities is to instill trust in them, to create a feeling that they will never be dominated by the majority and to homogenize the plurality in civil society and to integrate minorities fully and equally into the national life of the country characterized by the ethos and interests of the majority. The term minority appears only in Articles 29 and 30 of the Indian Constitution. Article 30 recognizes the right of minorities based on either religion or language to establish and administer educational institutions of their choice and prohibits the state from discriminating against educational institutions on the basis that it is under the management of the minority. Article 30 (1) has a very special place because through education alone minorities can preserve their language, characters and cultural heritage. It is the most important factor for human development as well as society. Even international law recognizes that education is a human right in general and also an important part of the rights of minorities. The concept of minority although not defined by the Constitution appears again in Article 29 of the constitution, in which the right of every part of citizens living in Indian territory, 'to' preserve 'a different language, script or culture is protected. Moreover, Articles 25 to 28 of the Constitution protect the religious and cultural rights of minorities. In addition to these rights, the articles in Part III of the Constitution which guarantee certain fundamental rights for either individual citizens or all persons, whether citizens or not, greatly strengthen this protection. It seeks protection from the activities of individual members of a group or part of the population either operating separately or together. They are often directed to promote these groups or their activities. Articles 29 and 30 of the constitution guarantee some defined rights and some unspecified rights for this minority group. The right to establish and manage educational institutions of their choice, for example, is a special right guaranteed by language and religious minorities. Such institutions can be established and managed by any section of the citizen who has a different language, script or culture to preserve it. The latter can also take reasonable steps to preserve language, script or culture. However, the most important reason for giving this right is the fact that minority groups realize that they need education for their survival and development.
\end{abstract}

JURNAL PAPATUNG: Vol. 2 No. 1 Tahun 2019

ISSN: 2715-0186 
If you want to preserve their cultural identity, you will tend to establish educational institutions where members can have a pleasant atmosphere that is conducive to the growth of their identity. The philosophy underlying the constitution is that no minority either based on religion, society or language is deprived of their rights or discriminated against in terms of admission to state educational institutions.

Keywords: Minorities, Right to Education, Article 29, Article 30, Constitution

\section{A. PENDAHULUAN}

Setiap masyarakat merupakan perpaduan budaya dan komunitas agama yang berbeda yang menghargai identitas mereka dan ingin melestarikannya. Sejalan dengan itu, seseorang dapat melihat pembagian penduduk menjadi mayoritas dan beberapa minoritas atas dasar komunitas agama dan budaya etnis. Meskipun setiap orang berhak untuk melindungi, melestarikan dan menjalankan keyakinan mereka, kelompok minoritas seringkali merasa diabaikan dan dipandang rendah. Oleh karena itu, penting bahwa untuk melindungi minoritas, identitas agama dan budaya mereka yang berbeda dilestarikan. Tujuan dasar dari perlindungan minoritas tersebut adalah untuk menanamkan kepercayaan kepada mereka, menciptakan perasaan bahwa mereka tidak akan pernah dikuasai oleh mayoritas dan untuk menghomogenkan kemajemukan dalam masyarakat sipil dan untuk mengintegrasikan minoritas secara penuh dan setara ke dalam kehidupan nasional negara bercirikan. oleh etos dan kepentingan mayoritas. Jawaharlal Nehru telah mengamati. Sejarah menunjukkan bahwa tidak akan ada keseimbangan yang stabil di negara mana pun selama ada upaya untuk menghancurkan minoritas atau memaksanya untuk menyesuaikan diri dengan cara mayoritas. Demokrasi terbesar di dunia juga dikatakan sebagai rumah bagi masyarakat paling beragam di dunia. Ini memiliki orang-orang dari semua agama besar. Meskipun Hindu JURNAL PAPATUNG: Vol. 2 No. 1 Tahun 2019

ISSN: $2715-0186$ 
merupakan mayoritas, tetapi ada juga sejumlah besar agama Muslim, Kristen, Parsees, Budha dan Jain. Keragaman di India terlihat di berbagai bidang selain agama dan budaya seperti bahasa. Keanekaragaman dibarengi dengan keragaman bahasa. Selain itu juga terdapat sejumlah Suku Terdaftar dan komunitas tertentu yang tidak teridentifikasi yang secara internal heterogen. Semua ini menjadikan India sebagai negara yang tidak hanya memiliki keragaman agama tetapi juga bahasa dan budaya.

Sebagai penjaga negara, konstitusi memberikan prinsip-prinsip dasar tertentu, di antaranya adalah penegakan hukum, persamaan dan ketentuan khusus bagi kelompok rentan tertentu. Konstitusi India memandang sekuler. Ini memvisualisasikan negara yang menawarkan keadilan, sosial ekonomi dan politik kepada semua warga negara. Kebebasan Berbicara dan Berekspresi dan Hak untuk Berserikat dan Bersatu dijamin untuk semua. Konstitusi India menjadikan India sebuah republik yang berdaulat, sosialis, sekuler, demokratis, yang terdiri dari pemerintahan perwakilan yang memperoleh kekuasaannya dari rakyat dan melaksanakan hal yang sama melalui perwakilan yang dipilih secara bebas oleh dan bertanggung jawab kepada rakyat. Pemerintah dijalankan oleh partai mayoritas dan kekuasaan politik didistribusikan di antara mereka. Hak-hak yang dijamin oleh Konstitusi tersedia untuk semua warga negara terlepas dari perbedaan apapun. Namun untuk melindungi minoritas agar tidak terhambat oleh mayoritas, konstitusi melangkah lebih jauh dengan mengadopsi sekelompok pasal tersendiri untuk menanamkan kepercayaan pada komunitas minoritas di negeri ini.

JURNAL PAPATUNG: Vol. 2 No. 1 Tahun 2019

ISSN: 2715-0186 
Istilah minoritas hanya muncul dalam Pasal 29 dan 30 Konstitusi. Pasal 30 mengakui hak minoritas baik berdasarkan agama atau bahasa untuk mendirikan dan menyelenggarakan lembaga pendidikan pilihan mereka dan melarang negara untuk mendiskriminasi lembaga pendidikan atas dasar bahwa ia di bawah pengelolaan minoritas. Konsep minoritas meskipun tidak didefinisikan oleh Konstitusi muncul lagi dalam Pasal 29 Konstitusi di mana hak setiap bagian dari warga negara yang tinggal di wilayah India 'untuk' melestarikan 'bahasa, aksara atau budaya yang berbeda dilindungi. Apalagi Pasal 25 hingga Pasal 28 UUD melindungi agama dan budaya minoritas. Selain hak-hak ini, pasal-pasal dalam Bagian III Konstitusi yang menjamin hak-hak fundamental tertentu baik bagi warga negara atau semua orang, baik warga negara atau bukan, sangat memperkuat perlindungan ini. Ini mencari perlindungan aktivitas individu anggota kelompok atau bagian dari populasi baik yang beroperasi secara terpisah atau bersama-sama. Mereka sering diarahkan untuk mempromosikan kelompok-kelompok ini atau aktivitas mereka.

\section{B. PEMBAHASAN}

\section{Pendidikan dan Hak Minoritas. Lembaga Pendidikan Minoritas}

Masalah minoritas sedemikian rupa sehingga menimbulkan penyelidikan tidak hanya di India tetapi di hampir semua negara demokratis karena demokrasi sejati membayangkan sebuah sistem di mana ada persamaan peluang bagi setiap komunitas di semua bidang dan memberikan kesempatan partisipasi di tingkat nasional. JURNAL PAPATUNG: Vol. 2 No. 1 Tahun 2019 ISSN: 2715-0186 
rekonstruksi tanpa kehilangan identitas terpisah mereka. Mengingat hal ini, konstitusi India membuat ketentuan khusus untuk kepentingan minoritas. Dari semua hak khusus yang diberikan kepada minoritas mungkin Pasal 30 (1) memegang tempat yang sangat khusus karena melalui pendidikan saja minoritas dapat melestarikan bahasa, aksara dan warisan budaya mereka. Itu adalah faktor terpenting bagi perkembangan manusia serta masyarakat. Bahkan hukum internasional mengakui bahwa pendidikan adalah hak asasi manusia secara umum dan juga bagian penting dari hak minoritas. Konstitusi menyatakan Pasal 30 (1) sebagai hak fundamental minoritas di India, baik berdasarkan agama maupun bahasa. Dalam draf aslinya, pasal ini tidak termasuk dalam kategori Hak Fundamental. Itu hanya kewajiban yang dibebankan pada negara dan pasal tersebut menetapkan batasan yang melarang negara untuk mengeluarkan undang-undang apa pun yang dapat disebut menindas. Pasal ini telah diberi status hak fundamental. Menjelaskan alasan melakukannya, B.R. Ambedkar menyatakan. Keadaan saat ini kita telah mengubahnya menjadi hak fundamental sehingga jika negara membuat undangundang yang tidak sesuai dengan ketentuan pasal tersebut maka sebagian besar undangundang itu tidak sah.

\section{Hak Pendidikan Minoritas: Mengapa dan Apa?}

Pertama-tama, penting untuk diperhatikan bahwa ada dua kelompok minoritas di India:

- Mereka yang berdasarkan agama atau bahasa yang merupakan minoritas permanen atau semu-permanen dalam hubungannya dengan orang India lainnya.

JURNAL PAPATUNG: Vol. 2 No. 1 Tahun 2019

ISSN: $2715-0186$ 
- Mereka yang merupakan minoritas sementara atau semi-sementara dalam kaitannya dengan segmen atau wilayah yang lebih kecil dari populasi India berdasarkan bahasa, aksara, atau bahasa.

Pasal 29 dan 30 konstitusi menjamin beberapa hak yang ditentukan dan beberapa hak yang tidak ditentukan untuk kelompok minoritas ini. Hak untuk mendirikan dan mengelola lembaga pendidikan pilihannya, misalnya, merupakan hak khusus yang dijamin oleh minoritas bahasa dan agama. Lembaga semacam itu dapat didirikan dan dikelola oleh setiap bagian warga negara yang memiliki bahasa, aksara atau budaya yang berbeda untuk melestarikannya. Yang terakhir juga dapat mengambil langkah yang wajar untuk melestarikan bahasa, naskah, atau budaya. Selanjutnya yang terpenting adalah mengetahui alasan pemberian hak mendirikan dan menyelenggarakan lembaga pendidikan. Jawabannya mungkin tidak berlaku secara universal untuk semua minoritas dalam suatu situasi.10 Misionaris Kristen dapat misalnya mendirikan lembaga pendidikan sekuler modern di daerah mayoritas non-Kristen untuk kepentingan yang terakhir. Mungkin seorang muslim, parsis, jain dan Sikh yang mendirikan institusi pendidikan untuk motif kebajikan seperti itu.

Konstitusi menjamin para pendiri lembaga tersebut semua yang dapat diklaim secara wajar di bawah kebebasan untuk mengelola dan mengelola. Pengadilan sejak awal telah menafsirkan hak penyelenggaraan lembaga minoritas secara sangat luas dan telah memperluas cakupannya. Hanya dalam beberapa kasus baru-baru ini pengadilan telah menyadari bahwa hak minoritas atas lembaga otonom dapat disalahgunakan untuk motif keuntungan, yang mengakibatkan penolakan hak untuk mengajar dan non- 
pengajar lembaga tersebut. Namun yang terpenting alasan pemberian hak tersebut adalah kenyataan bahwa kelompok minoritas menyadari bahwa mereka membutuhkan pendidikan untuk kelangsungan hidup dan perkembangan. Jika ingin melestarikan identitas budayanya maka akan cenderung mendirikan lembaga pendidikan di mana anggotanya dapat memiliki suasana yang menyenangkan yang kondusif bagi tumbuhnya identitasnya. Faktor terakhir ini cenderung menarik anak laki-laki dan perempuan dari komunitas yang tidak akan bergabung dengan lembaga lain dari kelompok dominan lainnya. Skema kelangsungan hidup yang sangat rasional dari setiap kelompok yang berbeda ini menuntut bahwa kebebasan memilih utama yang dijamin dalam pasal 30 (1) harus tersedia terutama dalam memutuskan jenis atau jenis pendidikan yang akan diberikan dan dalam memilih kelompok sasaran yaitu siswa dari kelompok tersebut. masyarakat sendiri yang kelangsungan hidup dan perkembangannya sebagai kelompok tersendiri seharusnya menjadi obyek jaminan konstitusional. Hak berdasarkan pasal 30 (1) adalah mutlak dan tidak seperti pasal 19 tidak mengakui pembatasan apa pun. Ini tidak berarti bahwa hak ini tidak tunduk pada kekuatan pengaturan negara. Negara dapat memberikan langkah-langkah pengaturan asalkan (1) tidak menghancurkan hak itu sendiri, (2) untuk kepentingan umum dan untuk kepentingan dan kepentingan lembaga. Tetapi penting juga untuk dicatat bahwa kekuatan pengaturan tidak boleh sedemikian rupa sehingga akan melanggar hak fundamental minoritas yang diberikan dalam pasal 30 (1) konstitusi.

Berkaca kembali pada asal mula artikel ini, sangat penting untuk dicatat bahwa Sub-Komite Minoritas yang dibentuk oleh Komite Penasihat Majelis Konstituante untuk 
Hak-Hak Fundamental dan Minoritas pada tanggal 24 Februari 1947 menyiapkan laporan sementara yang menangani pertanyaan tentang hak fundamental. dari sudut pandang minoritas dan diserahkan pada 19 April 1947. Laporan tersebut merekomendasikan hal-hal berikut:

- Semua warga negara berhak untuk menggunakan bahasa ibu mereka dan naskahnya, dan, untuk belajar atau menggunakan bahasa dan aksara lain apa pun yang mereka pilih.

- Minoritas di setiap unit harus dilindungi secara memadai sehubungan dengan bahasa dan budaya mereka, dan tidak ada pemerintah yang dapat membuat undang-undang atau peraturan yang dapat bertindak secara menindas atau merugikan dalam hal ini.

- Tidak ada minoritas baik agama, komunitas atau bahasa akan dirampas haknya atau didiskriminasi sehubungan dengan masuk ke lembaga pendidikan negara, dan tidak ada pelajaran agama wajib dikenakan pada mereka.

- Semua Minoritas 'baik agama, komunitas atau bahasa' bebas di setiap unit untuk mendirikan dan mengelola lembaga pendidikan pilihan mereka, dan mereka berhak atas bantuan negara dengan cara dan ukuran yang sama seperti yang diberikan kepada lembaga bantuan negara serupa .

- Terlepas dari adat istiadat, keputusan hukum atau penggunaan, anggapan dalam hal pengabdian, tidak ada orang Hindu atas dasar kasta, kelahiran atau denominasi dilarang memasuki lembaga pendidikan yang didedikasikan atau dimaksudkan untuk penggunaan komunitas Hindu atau bagiannya.

JURNAL PAPATUNG: Vol. 2 No. 1 Tahun 2019

ISSN: 2715-0186 
- Tidak ada diskualifikasi yang akan timbul dalam hitungan detik sehubungan dengan layanan publik atau profesi atau penerimaan ke lembaga pendidikan kecuali bahwa hal ini tidak akan mencegah pendirian lembaga pendidikan terpisah untuk anak laki-laki dan perempuan.

Ketika laporan ini dipertimbangkan oleh Komite Penasehat dalam pertemuannya yang diadakan pada tanggal 22 April 1947, Alladi Krishnaswami keberatan dengan klausul (i), berusaha untuk melindungi bahasa ibu adalah masalah yang tidak ada orang lain yang juga dapat mengganggu K.M. Munshi menjelaskan alasannya mengatakan bahwa klausul tersebut diambil dari hak minoritas di Polandia yang kemudian dimasukkan dalam Konstitusi Polandia. Dia mengatakan bahwa upaya dilakukan di Eropa dan tempat lain untuk mencegah minoritas menggunakan atau mempelajari bahasa mereka sendiri. Oleh karena itu, hak ini kemudian dianggap sebagai hak klasik minoritas.11 Terlepas dari desakan Munshi, klausul tersebut dihapus. Klausul (II) dan (III) diterima dengan sedikit modifikasi. Ada banyak diskusi tentang Klausul (IV) yang mengatur tentang hak mendirikan dan menyelenggarakan lembaga pendidikan dan hak atas bantuan negara. Salah satu keberatan atas pencantuman hak ini adalah bahwa hak tersebut akan melanggengkan lembaga-lembaga komunal dan bahwa negara seharusnya tidak memberikan bantuan kepada lembaga-lembaga tersebut.12 Namun keberatan tersebut tidak dapat meyakinkan panitia dan klausul yang sedikit diubah dalam bentuknya didukung oleh suara mayoritas. Klausul (V) dan (VI) dihapus sebagai redundan. Saran lain yang jika diterima akan mengguncang dasar-dasar yang menjadi dasar tuntutan dan pengakuan minoritas adalah G.B. Saran Pant bahwa hak yang JURNAL PAPATUNG: Vol. 2 No. 1 Tahun 2019 ISSN: 2715-0186 
direkomendasikan oleh sub-komite bisa lebih tepat dimasukkan sebagai prinsip-prinsip arahan yang akan tetap diperhatikan oleh undang-undang tetapi tidak akan dapat ditegakkan di pengadilan. Sementara Munshi menentang jika dibuat tidak dapat dibenarkan, Sardar ujjal singh dan Ruthnaswami menentang usulan tersebut dengan alasan bahwa perubahan hak ini dari status hak fundamental menjadi negara moral moral tidak akan diterima oleh minoritas.

\section{Komite Penasihat akhirnya datang untuk merekomendasikan hal-hal berikut:}

- Minoritas di setiap unit harus dilindungi sehubungan dengan bahasa dan budaya mereka, dan tidak ada undang-undang atau peraturan yang diberlakukan yang beroperasi secara menindas atau merugikan dalam hal ini.

- Tidak ada minoritas baik berdasarkan agama, komunitas atau bahasa yang akan didiskriminasi sehubungan dengan masuk ke lembaga pendidikan negara, dan tidak ada pelajaran agama yang wajib dikenakan pada mereka.

- Semua minoritas, baik berdasarkan agama, komunitas atau bahasa, akan bebas di unit manapun untuk mendirikan dan mengelola institusi pendidikan pilihan mereka.

- Negara tidak boleh, saat memberikan bantuan negara kepada sekolah, mendiskriminasi sekolah yang dikelola oleh kelompok minoritas baik berdasarkan agama, komunitas atau Bahasa.

Ketika rekomendasi ini datang ke hadapan Majelis Konstituante pada tanggal 1 Mei 1947 untuk penerimaan mereka, sebuah saran datang dari seorang anggota, Mahvir Tyagi agar pertimbangan seluruh masalah harus ditunda sampai diketahui apakah JURNAL PAPATUNG: Vol. 2 No. 1 Tahun 2019 ISSN: 2715-0186 
negara itu akan dipartisi dan jika demikian. perlakuan apa yang harus diberikan kepada minoritas di Pakistan atau di bagian manapun di India yang mungkin mengorganisir diri mereka sendiri secara terpisah. Untuk ini, B.R. Ambedkar mengatakan bahwa hak minoritas itu tidak relatif. Mereka mutlak dan tidak tunduk pada pertimbangan apa pun tentang apa yang mungkin ingin dilakukan Pakistan oleh pihak lain terhadap minoritas dalam yurisdiksinya sendiri. Namun, sub-ayat (2) dirujuk kembali dan Komite Penasehat untuk mengklarifikasi ruang lingkupnya sehubungan dengan lembaga-lembaga yang dibantu negara. Komite Penasihat menghapus kata 'dan tidak ada instruksi agama yang harus dipaksakan pada mereka' karena alasan mereka sudah dimasukkan dalam klausul 16. Beberapa anggota menginginkan amandemen ketika sub-klausul yang dirancang ulang (20 muncul di hadapan Majelis. Usulan Ahmad Ibrahim adalah bahwa larangan diskriminasi tidak boleh diterapkan pada lembaga pendidikan yang dibantu negara yang terutama didirikan untuk kepentingan masyarakat. komunitas tertentu. Mohanlal Saxena, anggota lain menyarankan agar tidak ada bantuan yang harus diberikan kepada lembaga pendidikan yang memberikan bantuan agama kecuali silabus memiliki persetujuan negara. Perubahan ini jika diberikan akan sangat mempengaruhi otonomi lembaga penerima bantuan dari negara Dana. Ibu Purnima Banerji menyarankan bahwa dalam lingkup klausul ini, harus dimasukkan lembaga-lembaga bantuan negara sehingga menjadi wajib bagi lembaga tersebut untuk tidak mendiskriminasi minoritas manapun dalam hal penerimaan. Ketiga amandemen tersebut tidak disetujui oleh majelis pada dasar bahwa itu adalah klausa non-diskriminatif sederhana dan perluasan Prinsip

JURNAL PAPATUNG: Vol. 2 No. 1 Tahun 2019

ISSN: 2715-0186 
ke st lembaga yang dibantu makan adalah prinsip yang dapat diputuskan oleh undangundang furnitur.

\section{Dengan demikian, setelah banyak pembahasan pasal 23 RUU konstitusi berbunyi sebagai berikut:}

- Setiap bagian dari warga negara yang tinggal di wilayah India atau bagian mana pun yang memiliki bahasa, aksara, atau budayanya sendiri yang berbeda berhak untuk melestarikannya.

- Tidak ada minoritas baik berdasarkan agama, komunitas atau bahasa, dapat didiskriminasi sehubungan dengan penerimaan setiap orang yang termasuk minoritas tersebut ke dalam lembaga pendidikan yang dikelola oleh Negara.

- Semua minoritas, baik berdasarkan agama atau bahasa, berhak untuk mendirikan dan mengelola lembaga pendidikan pilihan mereka.

- Negara tidak boleh, dalam memberikan bantuan kepada lembaga pendidikan, melakukan diskriminasi terhadap lembaga pendidikan atas dasar yang berada di bawah pengelolaan minoritas, baik berdasarkan agama atau bahasa.

Dengan demikian, Komite perancang membuat perbedaan antara hak setiap bagian dari warga negara untuk melestarikan bahasa, aksara atau budaya mereka dan hak minoritas berdasarkan agama atau bahasa untuk mendirikan dan mengelola lembaga pendidikan pilihannya, karena Komite menggantikan Kata 'minoritas' dengan bagian mana saja di bagian awal draf pasal 23 sementara tetap mempertahankan kata 'minoritas' di bagian terakhir, Saat memberikan penjelasan pada pasal tersebut 
Ambedkar menjelaskan bahwa. Perlu dicatat bahwa istilah minoritas digunakan di dalamnya bukan dalam arti teknis dari kata 'minoritas' karena kami telah terbiasa menggunakannya untuk tujuan perlindungan politik tertentu, seperti representasi di badan legislatif, representasi dalam layanan dan begitu seterusnya. Kata ini digunakan tidak hanya untuk menunjukkan minoritas dalam arti teknis dari kata tersebut, tetapi juga digunakan untuk mencakup minoritas yang bukan minoritas dalam arti teknis, tetapi tetap merupakan minoritas dalam pengertian budaya dan linguistik. Misalnya untuk tujuan pasal 23 ini, jika sejumlah orang dari madras datang dan menetap di Bombay untuk tujuan tertentu, mereka akan menjadi, meskipun bukan minoritas dalam pengertian teknis, minoritas budaya. Demikian pula jika sejumlah Maharastraian pergi dari Maharastra dan menetap di Bengal, meskipun mereka mungkin bukan minoritas dalam pengertian teknis, mereka akan menjadi minoritas budaya dan bahasa di Bengal. Pasal ini bermaksud untuk memberikan perlindungan dalam masalah budaya, bahasa dan aksara hanya kepada minoritas secara teknis tetapi juga minoritas dapat diartikan dalam arti sempit istilah ketika maksud dari Rumah ini ...... adalah menggunakan kata minoritas dalam lebih luas. Artinya, begitu ast o memberikan perlindungan budaya kepada mereka yang secara teknis bukan minoritas tetapi tetap minoritas. Dalam draf pasal dua lagi pasal yang bersifat substansial dimasukkan. Dengan satu perubahan kata 'bahasa, aksara dan budaya' diganti dengan kata 'bahasa, aksara atau budaya' pada ayat (1). Alasan amandemen dibahas oleh B.N Rao yang menunjukkan bahwa ada bagian orang dengan bahasa dan aksara terpisah tetapi tanpa budaya terpisah. Ada juga orangorang yang memiliki budaya terpisah tetapi tidak ada bahasa dan aksara yang terpisah.

JURNAL PAPATUNG: Vol. 2 No. 1 Tahun 2019

ISSN: 2715-0186 
Untuk ini dia menunjukkan bahwa klausul asli (1) tidak akan memberikan perlindungan apapun. Dia mencontohkan dengan mengatakan bahwa Muslim di Bengal tidak berbeda dari Hindu di sana dalam bahasa dan aksara tetapi memiliki budaya mereka sendiri yang berbeda, dan Andhras di Orissa memiliki aksara dan bahasa mereka sendiri tetapi tidak memiliki budaya yang berbeda dari mayoritas. dari penduduk. Amandemen lainnya berusaha melarang diskriminasi terhadap minoritas mana pun dalam hal penerimaan oleh lembaga bantuan negara. Ketika draf pasal 23 muncul untuk dipertimbangkan di hadapan Majelis Konstituante, Majelis menyaksikan banyak perdebatan amandemen dimajukan. Salah satu ketentuan menarik yang disarankan adalah dampak bahwa minoritas mana pun yang memiliki bahasa dan aksara yang berbeda harus berhak mendapatkan pendidikan dasar yang diberikan kepada anakanaknya melalui media bahasa dan aksara itu. Tetapi amandemen tersebut di atas tidak dapat diwujudkan dalam menghadapi tentangan dari berbagai pihak. Ballabh Pant menekankan bahwa pendidikan dasar itu penting dan harus dibuat universal. Tetapi karena melibatkan pengeluaran yang besar dan bahwa negara memiliki sumber daya yang terbatas, yang diinginkan adalah sebagai langkah pertama untuk memperkenalkan pendidikan dasar kepada sejumlah besar orang buta huruf di negara tersebut. Dia mengatakan bahwa jika harus ada dua atau tiga set guru (untuk mengajar bahasa yang berbeda), negara tidak akan dapat memperkenalkan pendidikan dasar universal atau pendidikan dasar wajib. Banyak lainnya juga mengungkapkan pandangan serupa bahwa ada kesulitan praktis untuk menerima pendidikan dasar dalam bahasa ibu sebagai hak yang dapat dibenarkan.

JURNAL PAPATUNG: Vol. 2 No. 1 Tahun 2019

ISSN: 2715-0186 
Ambedkar juga mengatakan bahwa meskipun memberikan pendidikan dasar dalam bahasa ibu tetapi tidak dapat dijadikan hak dasar yang dapat diberlakukan melalui pengadilan.20 Rancangan panitia kemudian di negara bagian revisi membagi pasal 23 menjadi dua pasal yang terpisah: Pasal 29 dan Pasal 30. 29 (1) Setiap bagian dari warga negara yang tinggal di wilayah India atau bagiannya yang memiliki bahasa, aksara atau budaya yang berbeda berhak untuk melestarikan yang sama. (2) Warga negara tidak boleh ditolak masuk ke lembaga pendidikan yang dikelola oleh negara atau menerima bantuan dari dana negara hanya atas dasar agama, ras, kasta, bahasa atau salah satunya. 30 (a) Semua minoritas, baik berdasarkan agama atau bahasa, berhak untuk mendirikan dan mengelola lembaga pendidikan pilihan mereka. (b) Negara dalam memberikan bantuan kepada lembaga pendidikan tidak boleh melakukan diskriminasi terhadap lembaga pendidikan atas dasar pengelolaannya oleh minoritas, baik berdasarkan agama maupun bahasa. Jadi, kecuali untuk beberapa konsesi yang diakui majelis untuk warga Anglo-India, tidak ada minoritas agama lain yang bisa mendapatkan hak politik apa pun. Konsesi kepada orang-orang anglo-India yang akhirnya dimasukkan dalam konstitusi terdiri dari ketentuan yang memberi wewenang kepada presiden untuk tidak mencalonkan lebih dari dua anggota komunitas anglo-India ke rumah orang jika menurut pendapatnya bahwa komunitas tersebut tidak terwakili secara memadai, hal serupa ketentuan pencalonan dalam dewan legislatif negara bagian, baik untuk jangka waktu 30 tahun saja, ketentuan reservasi di pos perkeretaapian, bea cukai, pos dan telegraf selama sepuluh tahun, reservasi tersebut atas dasar yang sama dengan yang ditetapkan sebelum tahun 1947. Selain itu ada ketentuan khusus dana 
pendidikan khusus selama sepuluh tahun yang tersedia bagi masyarakat pada tahun 1948. Majelis konstituante tidak memberikan hak politik apapun kepada minoritas lainnya. Apa yang akhirnya diakui ternyata adalah hak-hak yang berkaitan dengan pendidikan, bahasa dan budaya, dan kemudian dimasukkan sebagai pasal 29 dan 30 .

\section{KESIMPULAN}

Para perumus konstitusi tidak pernah bermaksud agar Pasal 29 (2) menjadi pengekangan atas isi hak pasal 30 (I). Bagaimana Pasal 29 (2) mengambil bentuk akhirnya di Majelis Konstituante dalam cerita yang menarik. Awalnya, Pasal 29 (2) saat ini adalah bagian dari skema terpadu yang dirancang untuk melindungi kepentingan pendidikan agama dan bahasa minoritas. Tujuan sederhana dari apa yang sekarang menjadi Pasal 29 (2) adalah untuk melindungi minoritas dari diskriminasi terkait dengan penerimaan di lembaga pendidikan negara. Rekomendasi Sub Komite minoritas yang dibuat pada tanggal 19 April 1947 untuk dimasukkan sebagai hak fundamental dalam konstitusi memuat ketentuan dalam klausul yang berbunyi: Tidak ada minoritas baik yang berdasarkan agama, masyarakat atau bahasa yang dicabut haknya atau didiskriminasi. menentang dalam hal masuk ke lembaga pendidikan negara. Komite penasihat menyetujui rekomendasi ini dan memasukkannya ke dalam laporan sementara. Saat datang ke hadapan majelis banyak terjadi perdebatan dan diskusi. Ambedkar merujuk klausul tersebut kembali ke komite penasihat untuk memperjelas ruang lingkupnya sehubungan dengan lembaga-lembaga bantuan negara yang tidak disebutkan dalam klausul tersebut. Ketika majelis mencari artikel yang dirancang ulang untuk 
dipertimbangkan, seorang anggota Majelis, Purnima Banerji membuat amandemen yang berusaha melarang lembaga-lembaga bantuan negara juga melakukan diskriminasi terhadap minoritas. Menjelaskan ruang lingkup pasal 18 (2), K. M. Munshi mengatakan bahwa ruang lingkup dibatasi pada hal ini dimana negara telah memiliki lembaga pendidikan sendiri, tidak boleh ada minoritas yang didiskriminasi. Sekarang ini tidak mengakui bahwa negara tidak dapat memiliki lembaga. Yang mengecualikan minoritas. Hak minoritas ini dimaksudkan untuk berpura-pura mencegah badan legislatif yang mengontrol mayoritas agar tidak memihak komunitas mereka sendiri hingga mengesampingkan komunitas lain. Beberapa anggota berusaha membuat amandemen yang sangat luas sehingga melarang semua institusi, baik yang dibantu oleh negara maupun negara, dari mendiskriminasi siapa pun yang termasuk minoritas atau mayoritas dalam hal penerimaan. Patel menolak semuanya dan mengatakan bahwa dia hanya ingin mengatakan bahwa ini adalah klausul non-diskriminatif sederhana terhadap minoritas dalam hal masuk ke sekolah yang dikelola oleh negara. Karenanya pasal 18 yang diadopsi oleh majelis menjadi pasal 23 rancangan konstitusi dengan perubahan rancangan tertentu. Sampai tahap ini tujuan majelis adalah untuk melindungi 'minoritas' dari diskriminasi dalam hal penerimaan. Hanya ketika draf artikel dibawa ke sidang, perubahan dramatis terjadi pada posisi ini. Pandit Thakurdas Bhargava tiba-tiba mengajukan perubahan pada draf ulang pasal 23 (2) menjadi: Tidak ada warga negara yang boleh ditolak masuk ke lembaga pendidikan yang dikelola sepenuhnya oleh negara atau menerima bantuan dari dana negara hanya atas dasar agama, bahasa, atau salah satunya. Menjelaskan amandemen tersebut, ia menunjukkan bahwa amandemen itu 
dimaksudkan untuk (I) memperluas hak masuk ke lembaga pendidikan untuk semua warga negara, apakah mereka milik mayoritas atau minoritas, dan (2) untuk menyediakan bahwa tidak hanya lembaga yang dikelola negara tetapi juga penerima bantuan dari dana negara akan dilarang melakukan diskriminasi dalam hal penerimaan. Majelis menerima amandemen dan, dengan itu, penjelasan Bhargawa. Apa yang mendorong majelis untuk menerima amandemen Bhargawa yang menggantikan kata 'minoritas' oleh 'warga' tidak diketahui karena majelis memilih untuk tidak menetapkan apapun. Namun diketahui bahwa perhatian majelis tidak tertuju pada konflik nyata antara apa yang sekarang pasal 29 (2) dan pasal 30 (1). Majelis tidak memperhatikan konflik yang tampak ini, dapat menawarkan dua kemungkinan alasan:

- Majelis, secara tidak langsung bermaksud untuk secara tidak langsung menghilangkan apa yang dimaksudkan untuk Mengakui minoritas secara langsung dengan menempatkan pasal 29 (2) sebagai pengecualian terhadap pasal $30(1)$

- Majelis, dalam perkiraannya, tidak menemukan pasal 29 (2) bertentangan dengan pasal 30 (1) dan dengan demikian pengecualian terhadap pasal 30 (1)

Kemungkinan pertama harus dikesampingkan karena majelis tidak dapat mengharapkan hasil yang absurd. Alternatifnya, hanya kemungkinan kedua yang dapat diandalkan untuk menyimpulkan niat para perumus bahwa yang mereka maksud bukan pasal 29 (2) sebagai pengecualian dari pasal 30 (1). Faktor-faktor berikut tampaknya membantu memperkuat ketergantungan ini:

JURNAL PAPATUNG: Vol. 2 No. 1 Tahun 2019

ISSN: 2715-0186 
- Penjelasan Bhargawa untuk substitusi kata 'minoritas' dengan kata Warga dalam pasal 29 (2) tidak berbeda dengan bentuk Ambedkar yang menggantikan kata 'Minoritas' dengan kata 'bagian manapun dari warga', membuat manfaat dari Pasal 29 (1) tersedia untuk kelompok lain serta, tanpa, pada saat yang sama, mengorbankan objek nyata untuk mencapai mana Pasal 29 (1) dimasukkan.

Pembacaan dekat dari penjelasan Bhargawa tentang amandemen tersebut menunjukkan bahwa dia, seperti Ambedkar, tidak ingin mengubah pasal 30 (1). Apa yang dia inginkan adalah untuk menyediakan kepada siswa dari komunitas mayoritas juga hak yang akan diberikan oleh Majelis kepada minoritas, dengan demikian mencoba untuk memperluas ruang lingkup pasal 29 (2) tanpa menyentuh hak khusus yang tersedia untuk minoritas berdasarkan pasal 30 (1). Bhargava menjelaskan bahwa perubahan kedua yang ingin dibuat oleh amandemen ini adalah terkait dengan institusi yang akan diatur oleh Ketentuan hukum ini. Sebelumnya hanya lembaga pendidikan yang dikelola negara yang dimasukkan. Ini termasuk lembaga lain yang dibantu oleh dana negara. Ada banyak sekali institusi dan ke depan dengan amandemen ini hak-hak minoritas diperluas dan hak-hak mayoritas juga dijamin.

- Jika para perumus bermaksud untuk membuat larangan menurut ayat (2) pasal 29 tersedia terhadap lembaga minoritas dengan memperlakukan sama sebagai pengecualian terhadap hak berdasarkan pasal 30 (I), tempat yang paling tepat untuk memasukkan tersebut adalah pasal (30) itu sendiri dan bukan pasal 29. Jelas bahwa jika para perumus yakin bahwa mereka memperlakukan klausa

JURNAL PAPATUNG: Vol. 2 No. 1 Tahun 2019

ISSN: $2715-0186$ 
- (2) dari Pasal 29 sebagai pengecualian, tidak ada yang dapat mencegah mereka untuk menandai pengecualian pada Pasal 30 yang berusaha untuk memasukkan aturan umum. Jika larangan itu dimaksudkan sebagai pengecualian terhadap pasal 30 (I). para perumus bisa saja menggunakan kata-kata seperti 'tunduk pada ketentuan pasal 29 (2)' pada pembukaan jika pasal 30 (2) atau 'terlepas dari apapun yang terkandung dalam pasal 30 (I)' pada pembukaan pasal 29 (2) .

Karena mereka tidak melakukannya, jelas bahwa maksud para perumus bukanlah untuk memperlakukan pasal 29 (2) sebagai pengecualian terhadap pasal 30.

\section{DAFTAR PUSTAKA}

Rahim, R. (2012). Signifikansi pendidikan multikultural terhadap kelompok minoritas. Analisis: Jurnal Studi Keislaman, 12(1), 161-182.

Ibrahim, R. (2015). Pendidikan Multikultural: Pengertian, Prinsip, dan Relevansinya dengan Tujuan Pendidikan Islam. Addin, 7(1).

Wahyuddin, W., Kasan, W., \& Wekke, I. S. (2018). Pembinaan Aqidah di Panti Asuhan Minoritas Muslim.

Freire, P. (2000). Pendidikan kaum tertindas. LP3ES.

Farihah, I., \& Izzati, A. (2016). Pendidikan kaum minoritas. Edukasia: Jurnal Penelitian Pendidikan Islam, 11(1).

Wekke, I. S. (2013). Pengembangan kurikulum pendidikan agama Islam muslim minoritas: pesantren Nurul Yaqin Papua Barat. Madrasah: Jurnal Pendidikan dan Pembelajaran Dasar, 5(2), 26.

Wahib, A. (2011). Pergulatan pendidikan agama Islam di kawasan minoritas muslim. Walisongo: Jurnal Penelitian Sosial Keagamaan, 19(2), 467-482.

Wekke, I. S. (2017). Integrasi Pendidikan Islam dan Pembelajaran Kewirausahaan di Pesantren Minoritas Muslim. Fenomena, 9(1), 1-24.

Hoesin, I. (2003, July). Perlindungan terhadap kelompok rentan (wanita, anak, minoritas, suku terasing, dll) dalam perspektif hak asasi manusia. In Makalah dalam Seminar Pembangunan Hukum Nasional VIII Tahun.

JURNAL PAPATUNG: Vol. 2 No. 1 Tahun 2019

ISSN: 2715-0186 